\title{
Trends and Regional Patterns of Cross-Border Mergers and Acquisitions: A Case of Malaysian and Indonesian Acquirers
}

\author{
Mohd Haniff Jedin
}

Abstract

\begin{abstract}
Progress of cross-border mergers and acquisitions (M\&A) in Asian region demonstrates an upstream pattern although the economy in Europe is unhealthy. In fact, many cross-border deals in Europe are dominated by Asian and US acquirers. In 2010, Asia Pacific countries had completed over 8,300 M\&A deals that involved an Asian company reported by Dealogic. Countries such as China, South Korea, Malaysia, Singapore and Thailand are among Asian countries that are active in cross-border M\&A. However, M\&A trends in Malaysia and Indonesia have not received due attention of the researchers. Present study attempts to explore this phenomenon with the specific idea of identifying the background of Malaysian and Indonesian industries that involved in cross-border M\&A. Present paper also reveals the integration trends involved when engaging in cross-border $M \& A$. An opinion survey was conducted of the firms involved in $M \& A$ deals; the companies were identified from the Thomson One Banker main database which covers cross border M\&A cases completed in Malaysian and Indonesia. Results show that engineering, software and telecommunication industries are among the leading industries engaged in cross-border M\&A. Results also reflect that in terms of nationality of the acquired firms, Malaysia, Indonesia, Thailand and Singapore are among favourites to Malaysian and Indonesian acquirers. The study highlights higher success compared to failures in cross-border M\&A in the countries under reference.
\end{abstract}

Keywords: Cross-border mergers and acquisitions, management styles, marketing integration.

\section{Introduction}

In brief, Mergers and acquisitions (M\&A) can be defined separately; mergers is a combination of assets of two previously separate firms into a single new legal entity whereas acquisition is the control of assets transferred from one company to another (Ghauri and Buckley 2003).However, according to United Nations (2000), the number of mergers are relatively low therefore for practical purposes M\&A should also reflect 'acquisitions'. Furthermore, M\&A can be categorised into three main groups: horizontal, vertical and conglomerate and can be classified further into domestic M\&A and cross-border M\&As. 
For the purpose of this study on Cross-border M\&A an attempt is made to highlight several evidences about the amalgamation of Malaysian and Indonesian and the rest of other nations. In addition this study will look at the patterns of amalgamation particularly to identify the form of M\&A that Malaysian and Indonesian firms have engaged. The paper is presented in three main sections: in the first section it discusses previous studies in crossborder M\&A. The next section addresses the research methodology that is applied in this research. Finally, the findings concludes the amalgamation patterns among Malaysian firms that employ cross-border M\&A are presented.

\section{Cross-Border Mergers and Acquisitions}

The increasing trend of cross-border or international M\&A has been motivated by a variety of strategic considerations, which normally differ from purely domestic M\&A. Compared to domestic M\&A, cross-border M\&A has more challenges in increasing the firms' value and wealth because it involves different environments, cultures, policies and procedures. According to Zaheer (1995) companies engaging in cross-border M\&A are facing unique risks, such as 'liability of foreignness and double-layered acculturation'. It means differences in national culture, customer preferences, business practices and institutional forces, such as government regulations do have negative externalities in M\&A deals and hence can pose major challenges to companies in realizing their strategic objectives fully.

Historically, research on international expansion of firms were focused primarily on the decision to export, versus the use of FDI (Fladmoe-Lindquist, 1996). For instance, business expansion via cross-border M\&A is popular among the multinational companies. It is also known as an agronomic business expansion. In addition to this, Gaughan (2002) points out in his book that expansion is one of the most common motives for merger and acquisition. He discusses further that international M\&A can be a quicker way to expand than internal expansion. However, business through cross-border M\&As are more complex, owing to differences in political and economic environment, corporate organization, culture, tradition, tax rules, law and accounting rules between the countries of the acquirer and the target firm (Sudarsanam, 2003).

Furthermore, Shimizu et al. (2004) noted that the entry mode via cross-border M\&As can be used to access new and lucrative markets, as well as expand the market for a firm's current goods. In addition, firms are able to expand their capabilities as well as their networking while using the acquired firms' resources. He further stressed that basically, the choice of a cross-border M\&A as a mode of entry into foreign market is often influenced by 1) firm-level factors such as multinational experience, local experience, product diversity, and international strategy; 2) industry-level factors such as technological intensity, advertising intensity and sale force intensity and 3) country-level factors such as market growth in the host country, cultural idiosyncrasies between home and host countries and the specific culture of the acquiring firm's home country (uncertainty avoidance and risk propensity) (Shimizu et al., 2004) 
Another valuable finding from cross-border M\&A is the motives behind the deals. Hopkins et al. (1999) explains that basically there are four distinct but related motives: strategic, market, economic and personal. Among these motives, market motive shows the most significant to this study, whereby M\&A is used as an alternative to enter new markets in new countries. Most of all, it discusses using M\&A as a very quick and sound way to gain a strong position or at least at par with the local market leader. For example, in 1997, Mutiara Telecommunication was acquired by Digi.Com, which was owned by Digi Swiss.Com. Today, based on the number of subscribers, they are the third largest cellular telecommunication network service provider in Malaysia (Prathaban, 2006).

In Malaysia particularly, the applications of M\&A were chaotic in 1999, when the banking industries were urged by the Malaysian Central Bank to integrate and combine into only six major groups (Shanmugam \& Nair 2003). These banks were to be known as the "anchor banks". It was believed that this strategy was a conscious attempt by the central bank to prepare the local banks to face the liberalization in banking industries, specifically with the emergence of Asia Free Trade Area (AFTA). The best example was when Maybank one of the leading banks in Malaysia legally owned 93.92\% of PT Bank Maybank Indocorp in Indonesia (Abidin, 2008).

In fact, the Malaysian government recognized the cross-border M\&A as one of the tools in GLCs (government-linked companies) transformation plan, that is known as cross border expansion and diversification (Barrock, 2006). For instance, Telekom Malaysia Berhad (TM) and Maxis communication Berhad, two local telecommunication companies, have ventured abroad by using M\&A to acquire firms in India and Indonesia (Jayaseelan, 2006). In Indonesia, Maxis owns PT NatrindoTelepon Seluler, while TM has taken over PT Excel comindo. In India, Maxis acquired Aircel and TM acquired Spice. Latest development of cross-border M\&A integration was executed between CIMB and Manila-based Bank of Commerce for RM881 million (Ahsan, 2012).

Despite the substantial evidences of M\&As phenomenon, many of the cross-border M\&A studies are generally fragmented (Larsson \& Finkelstein, 1999; Shimizu et al., 2004), scattered (Kish \& Vasconcellos, 1993) and depends on industry (Hopkins et al., 1999). There are however limited number of studies addressing the patterns and trends of cross-border M\&As in Asia with the exception of the study conducted by Metwalli and Tang (2002). Therefore, this study is timely and relevant to help improve Malaysian and Indonesian firms in cross-border M\&A strategy.

\section{Methodology}

A survey was used to collect the data in 2008 focusing on cross-border M\&A transactions undertaken by Malaysian and Indonesian firms, over a period of seven years (2000-2006). This seven-year period was chosen because it represents the recovery period for South East Asian countries, especially Malaysia, Thailand and Indonesia, following the Asian financial turmoil of 1997-1999 (United Nations, 2000). The M\&A cases were collected from the 
Thomson One Banker database. At the same time, this research has also cross-verified the selected cases with the local stock exchange agencies: for Malaysia the Securities Commission and Bursa Malaysia and for Indonesia, the Indonesian Business Directory, the Jakarta Stock Exchange and the Indonesian Investment Coordination Board.

A minimum value for the cross-border transactions included a sample of 1 million US dollars, which is lower than the 10 million US dollars proposed by Kogut and Singh (1988). The rationale behind this is that the currencies and the size of the firms in countries such as Malaysia and Indonesia is not as high and most of the transaction values are lower than in developed countries. If a threshold of 10 million US dollars is used, it would have a much smaller sample. On the other hand, according to the transaction values reported by the Securities Commission Malaysia and the Jakarta Stock Exchange, most of the transactions with less than 1 million US dollars were acquisitions by internal shareholders and were unlikely to involve departmental integration let alone to be cross-border M\&A. Finally, there is no restriction of the sample to any particular sector or industry.

Out of the 1697 M\&A cases listed in Thomson One Banker, this research identified 250 completed, cross-border cases involving Malaysian acquirers and 18 involving Indonesian acquirers. Of these, nine from Malaysia and three from Indonesia were discarded as they were acquisitions by shareholders or investor groups. Next, those cases with a value greater than 1 million US dollars were indentified leaving a final sample of 163 qualifying cases. Companies were then contacted to identify contact persons, explaining in detail the survey process involved. As a result of this, 17 more cases were discarded as the contact persons were unwilling to participate, leaving 146 cases remaining.

In order to increase number of responses, various follow-up method was applied, following the tailored design method of Dilman (2007). The most useful collection method was email (sending the survey as an attachment), followed by collecting the survey in person. Mail survey results were found to be second, although additional questionnaires were sent out to encourage the respondents to participate. In the end, 112 questionnaires we received, of which 109 were useable.

\section{Results}

\section{Industry Background}

A multiple rather than a single-industry survey was conducted. The rational for this approach was that, there have been fewer cases of cross-border M\&As in Malaysia and Indonesia compared to developed countries such as the US and European countries. In fact, many recent M\&A studies have employed a multiple-industry approach (Cording et al., 2008; Homburg \& Bucerius 2005; Richey et al., 2008). The industries were identified using an ordinal scale, which easily allowed the respondents to identify their particular industry. There 
were sixteen industry groups to choose from in the questionnaire including a catch-all entitled 'other industry', which was crucial as a number of respondents selected. The distribution of industries, including those marked 'other industry' is presented in Table-1. However, overall, there were 40 industries including missing data. This type of industry classification has also been used by other researchers in M\&A studies (Cording et al., 2008; Homburg and Bucerius 2005; Richey et al. 2008). It is suitable here as there are not many cases and it serves to highlight each industry in detail. We also specify the actual sample data (cases) obtained from the survey. This is crucial as we can see a pattern in which industries contributed to the study. We received 109 useable questionnaires (15 from Indonesia and 94 from Malaysia). Where there was missing data for this question, we identified the industry from the respondent's email address, which was provided at the end of the questionnaire. Table-2 shows that engineering, software and telecommunication industries are among the leading industries engaged in cross-border M\&A.

Table 1

Distribution of Collected Cases in Industry

\begin{tabular}{lcccc}
\hline \multicolumn{1}{c}{ Industry } & Number of Cases & $\begin{array}{c}\text { Non Response } \\
\text { Cases }\end{array}$ & $\begin{array}{c}\text { Missing / } \\
\text { Incomplete }\end{array}$ & $\begin{array}{c}\text { Collected } \\
\text { Cases }\end{array}$ \\
\hline Automotive & 6 & 2 & 4 \\
Brokerage and Commodity & 4 & 1 & 3 \\
Computing and Wireless & 5 & 3 & 2 \\
Construction & 7 & & 7 \\
Construction Materials & 2 & 1 & 1 \\
Chemical & 3 & 2 & 1 \\
Clothing & 5 & 3 & 2 \\
Consulting & 3 & 1 & 2 \\
Property Developer & 2 & & 2 \\
Electronics & 7 & 0 & 6 \\
Engineering & 7 & 2 & 5 \\
Food and Beverages & 6 & 2 & 4 \\
Other Financial services & 6 & 4 & 1 \\
Furniture & 1 & & & 1 \\
Healthcare Equipment & 3 & & & 1 \\
Health Products & 1 & & & 1 \\
High Technology & 1 & & & 1 \\
Hotel Services & & & & 1 \\
\hline
\end{tabular}




\begin{tabular}{|c|c|c|c|c|}
\hline Industry & Number of Cases & $\begin{array}{c}\text { Non Response } \\
\text { Cases }\end{array}$ & $\begin{array}{c}\text { Missing / } \\
\text { Incomplete }\end{array}$ & $\begin{array}{c}\text { Collected } \\
\text { Cases }\end{array}$ \\
\hline Household and Consumers & 3 & 1 & & 2 \\
\hline Investment Banks & 3 & & & 3 \\
\hline Insurance & 3 & 1 & & 2 \\
\hline Machinery & 6 & 5 & & 1 \\
\hline Manufacturing & 5 & 2 & & 3 \\
\hline Manufacturing Equipment & 2 & 1 & & 1 \\
\hline Media Broadcasts & 1 & & & 1 \\
\hline Metal and Mining & 3 & 1 & & 2 \\
\hline Oil \& Gas Products & 8 & & & 8 \\
\hline Publishing and Advertising & 2 & & & 2 \\
\hline Petrochemical & 3 & & & 3 \\
\hline Packaging & 1 & & & 1 \\
\hline $\begin{array}{l}\text { Plantation and } \\
\text { Agribusiness }\end{array}$ & 6 & 2 & & 4 \\
\hline Pharmaceutical & 3 & 1 & & 2 \\
\hline Retail Banking & 3 & & & 3 \\
\hline Retailing & 2 & & & 2 \\
\hline Software & 8 & 1 & 1 & 6 \\
\hline $\begin{array}{l}\text { Transportation and } \\
\text { Logistics }\end{array}$ & 2 & & & 2 \\
\hline Telecommunications & 7 & 1 & & 6 \\
\hline Trading and Wholesale & 2 & & & 2 \\
\hline Utilities and Infrastructure & 3 & & & 3 \\
\hline Missing & & & & 3 \\
\hline Total Industry (cases) & 146 & 37 & 3 & 109 \\
\hline
\end{tabular}

Table 2

Industries that Engaged in Cross-border $M \& A$

\begin{tabular}{lccc}
\hline \multicolumn{1}{c}{ Acquirer Firm } & Acquired Firm & Industry & $\begin{array}{c}\text { Country of } \\
\text { Acquired firm }\end{array}$ \\
\hline Jotech Metal \\
Fabrication Ind
\end{tabular}




\begin{tabular}{|c|c|c|c|}
\hline Acquirer Firm & Acquired Firm & Industry & $\begin{array}{l}\text { Country of } \\
\text { Acquired firm }\end{array}$ \\
\hline Ingress Corp Bhd & $\begin{array}{l}\text { Fine Components(Thailand) } \\
\text { Co }\end{array}$ & Engineering & Thailand \\
\hline Nylex(Malaysia)Bhd & CKG Chemicals Pte Ltd & Engineering & Singapore \\
\hline UMW Petropipe & $\begin{array}{l}\text { Vina Offshore Holdings Pte } \\
\text { Ltd }\end{array}$ & Engineering & Singapore \\
\hline $\begin{array}{l}\text { Sime Overseas Sdn } \\
\text { Bhd }\end{array}$ & $\begin{array}{l}\text { WeifangSime Darby Port Co } \\
\text { Ltd }\end{array}$ & Engineering & China \\
\hline $\begin{array}{l}\text { Sime Overseas Sdn } \\
\text { Bhd }\end{array}$ & $\begin{array}{l}\text { WeifangSime Darby Water } \\
\text { Co Ltd }\end{array}$ & Engineering & China \\
\hline $\begin{array}{l}\text { EngTeknologi } \\
\text { Holdings Bhd }\end{array}$ & Altum Precision Pte Ltd & Engineering & Singapore \\
\hline $\begin{array}{l}\text { SapuraCrest } \\
\text { Petroleum Bhd }\end{array}$ & Total Marine Technology Pty & Engineering & Australia \\
\hline $\begin{array}{l}\text { Formosa } \\
\text { ProsonicInds Bhd }\end{array}$ & Winmax Holdings Group Ltd & Engineering & Hong Kong \\
\hline $\begin{array}{l}\text { YTL Power } \\
\text { International Bhd }\end{array}$ & Jawa Power PT & Engineering & Indonesia \\
\hline $\begin{array}{l}\text { TM International Sdn } \\
\text { Bhd }\end{array}$ & $\begin{array}{l}\text { Cambodia SamartCommun } \\
\text { Co Ltd }\end{array}$ & Telecommunication & Cambodia \\
\hline $\begin{array}{l}\text { TM International } \\
\text { SdnBhd }\end{array}$ & Spice Communications Ltd & Telecommunication & India \\
\hline $\begin{array}{l}\text { TM International } \\
\text { SdnBhd }\end{array}$ & Samart I-Mobile PCL & Telecommunication & Thailand \\
\hline $\begin{array}{l}\text { Maxis } \\
\text { Communications Bhd }\end{array}$ & $\begin{array}{l}\text { Global CommunSvesHldgs } \\
\text { Ltd }\end{array}$ & Telecommunication & Mauritius \\
\hline $\begin{array}{l}\text { Maxis } \\
\text { Communications Bhd }\end{array}$ & Aircel Ltd & Telecommunication & India \\
\hline GMO Global Ltd & $\begin{array}{l}\text { Wisdom Choice Investments } \\
\text { Ltd }\end{array}$ & Telecommunication & China \\
\hline $\begin{array}{l}\text { AKN Messaging } \\
\text { Technologies Bhd }\end{array}$ & Surya Genta Perkasa PT & Telecommunication & Indonesia \\
\hline
\end{tabular}

\section{Country of Origin of the Acquired Firm}

Table 2 shows the distribution of countries of origin of the acquired firms involved in the cross-border M\&As undertaken by the Malaysian and Indonesian firms surveyed. 
According to the results, the largest segment of firms targeted by the Malaysian firms came from Indonesia (17 cases). In contrast, the Indonesian firms acquired only one Malaysian firm. The table also shows that four other countries also feature highly, namely China (11 cases), India (9 cases), Singapore (13 cases) and Thailand (14 cases). All of these countries are among the most popular countries for Malaysian and Indonesian firms to penetrate using the cross-border M\&A strategy. Overall, the target firms were from 29 countries.

\section{Table 3}

Country of Origin of the Acquired Firm

\begin{tabular}{|c|c|c|}
\hline Country & $\begin{array}{l}\text { Number of M\&A Cases Acquired } \\
\text { by Malaysia. }\end{array}$ & $\begin{array}{l}\text { Number of M\&A Cases Acquired } \\
\text { by Indonesia }\end{array}$ \\
\hline Australia & 4 & 2 \\
\hline Bangladesh & 1 & \\
\hline Brunei & 1 & \\
\hline Cambodia & 2 & \\
\hline China & 9 & 2 \\
\hline Egypt & 1 & \\
\hline France & 1 & \\
\hline Germany & 1 & \\
\hline Hong Kong & 1 & 1 \\
\hline India & 9 & \\
\hline Indonesia & 17 & \\
\hline Italy & 1 & \\
\hline Japan & 1 & \\
\hline Malaysia & 1 & 3 \\
\hline Mauritius & 2 & \\
\hline Netherlands & 3 & \\
\hline New Zealand & 1 & \\
\hline Pakistan & 1 & \\
\hline Philippines & 2 & \\
\hline Singapore & 8 & 5 \\
\hline South Africa & 1 & \\
\hline Sri Lanka & 1 & \\
\hline
\end{tabular}




\begin{tabular}{lcc}
\hline Country & $\begin{array}{l}\text { Number of M\&A Cases Acquired } \\
\text { by Malaysia. }\end{array}$ & $\begin{array}{l}\text { Number of M\&A Cases Acquired } \\
\text { by Indonesia }\end{array}$ \\
\hline Sudan & 1 & \\
Taiwan & 4 & 1 \\
Thailand & 13 & 1 \\
United Kingdom & 5 & \\
United States of & 4 & 15 \\
America & 2 & \\
Vietnam & 94 & \\
\hline Total & & \\
\hline
\end{tabular}

\section{Types of M\&A}

As this study looks at multiple industries rather than focusing on a single industry, we divided the sample by the type of M\&A as proposed by Kitching (1967). Kitching's study established the underlying causes for variations in M\&A performance using a sample of 22 companies involved in 69 acquisitions. The study investigated five types of M\&A, namely, horizontal, vertical, conglomerate, concentric marketing and concentric technology. However, we have employed only three of these. We exclude concentric marketing and concentric technology as these M\&A types are very specific and may have confused the respondents. Table 3 shows the distribution of our sample by type of M\&A. Horizontal M\&As dominate (56\%). Vertical and conglomerate make up $28 \%$ and $16 \%$ of the sample respectively.

Table 4

Distribution of $M \& A$ Characteristics

Characteristics of M\&A

Horizontal

Vertical

Conglomerate
Frequency

68

26

15
62.4

23.9

Percentage (\%)

13.8 


\section{Involvement of Cross-Border M\&A among Malaysian and Indonesian Acquirers}

Table 4 shows the distribution of cross-border M\&A involvement which refers to the period elapsed from the date of the corresponding M\&A. The data were grouped into four categories: 1-5 years, 6-10 years, 11-20 years and more than 20 years of experience. The most frequently observed category was 1-5 years of experience indicating that most of the firms involved in cross-border M\&As in Malaysia and Indonesia are still new and most probably still learning and adapting to this international business strategy. The category of 6-10 years comprised 37 of the sample and 11-20 years made up 20. Just one company (from Malaysia) had more than 21 years of experience in cross-border M\&As.

Table 5

Distribution of Experience in Cross-Border M\&As among the Malaysian and Indonesian Acquiring Firms

\begin{tabular}{lccccc}
\hline \multicolumn{1}{c}{ Experience of Cross-Border M\&As } & \multicolumn{2}{l}{ Indonesia } & \multicolumn{2}{c}{ Malaysia } & Total \\
\hline 1 to 5 Years & 11 & $73.3 \%$ & 40 & $42.6 \%$ & 51 \\
6 to 10 Years & 3 & $20 \%$ & 34 & $36.2 \%$ & 37 \\
11 to 20 Years & 1 & $6.7 \%$ & 19 & $20.2 \%$ & 20 \\
More than 21 Years & 0 & 0 & 1 & $1.1 \%$ & 1 \\
\hline Total & 15 & $100 \%$ & 94 & $100 \%$ & 109 \\
\hline
\end{tabular}

\section{Advisor of M\&A}

According to Allen et al. (2004), commercial banks or investment banks usually act as lenders and at the same time as advisors on M\&A transactions. These advisors also sometimes act as middlemen to secure the relationship between the acquirer and the target firm. They are also a key party determining the speed and the probability of completing the M\&A deal (Hunter \& Jagtiani, 2003). On the other hand, consultant firms are also important as their function is more specific such as to provide operational advisory services between the acquirer and the target firms (Aspan, 2009). Nevertheless, both the banks and the consultants are important in assisting to shape strategy, to locate a target and to advise on mounting a bid or on the price of a potential M\&A (Angwin, 2001). Table 27 shows that $33 \%$ of the acquirers employed financial institutions to act on their behalf in 
M\&A transactions. Nearly $28 \%$ of the respondents employed both banks and consultant firms as their middlemen. $25.7 \%$ of the respondents employed consultant firms as their middlemen and finally $12.8 \%$ of respondents failed to answer this question.

Table 6

Distribution of Advisor among the Malaysian and Indonesian Acquiring Firms

\begin{tabular}{lcc}
\hline \multicolumn{1}{c}{ Advisor } & Frequency & Percentage $(\%)$ \\
\hline Financial Institution/Banks & 36 & 33 \\
Consultant Firm & 28 & 25.7 \\
Both (Banks and consultant) & 31 & 28.4 \\
Missing & 14 & 12.8 \\
\hline Total & 109 & 100 \\
\hline
\end{tabular}

\section{Perception of Firm's Amalgamation}

The survey results showed that nearly $69 \%$ of the respondents had a successful experience of the amalgamation of the target firm and the acquiring firm. Meanwhile, $16 \%$ of the respondents assessed their experience as moderate and, finally, $15 \%$ said they were unsuccessful. These figures are shown in Figure 2.

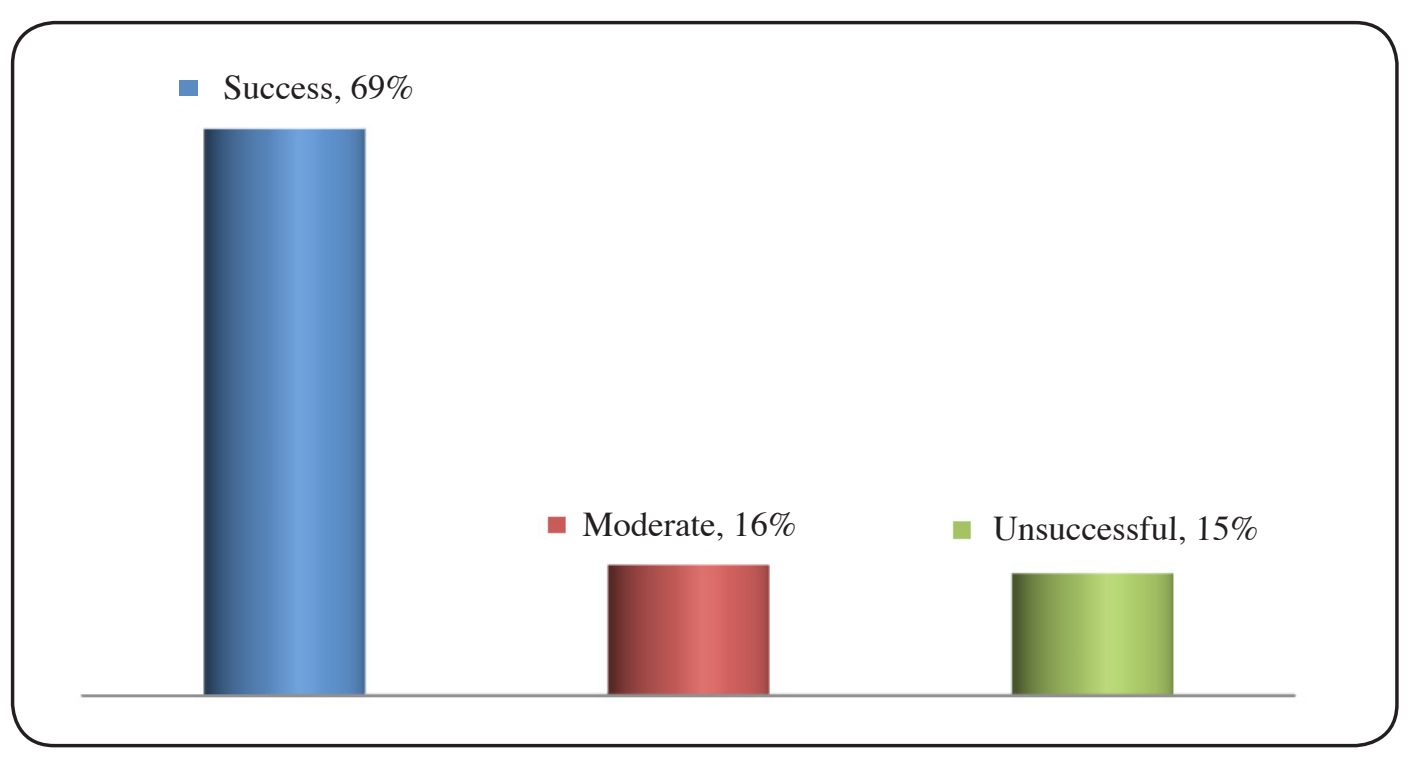

Figure 2. Perceive of M\&A Amalgamation. 


\section{M\&A Performance among Malaysian and Indonesian Acquirers}

Strikingly, few past studies have dealt with the performance associated with various acquisition strategies (Kusewitt, 1985). Therefore, we propose using acquisition performance measures that were employed by Colombo et al. (2007). Colombo and his colleagues investigated integration in cross-border acquisitions. They employed five items to measure M\&A performance: market share, intrinsic profitability (ROI), competitive position, market coverage and customer satisfaction (Table 6). All of these items were measured using perceptual measurement. The present study is based on a seven-point Likert-type scale (1 $=$ substantially worse; 7 =substantially better) instead of the three-point Likert-type scale (significant decline, stable and significant increase) proposed by Colombo. This is very important to maintain the respondents' inclination to participate in the questionnaire, as most of the questions have used a seven-point Likert-type scale.

'Market share' is the most significant driver of the cross-border M\&A among Malaysian and Indonesian acquirers. This is followed by 'improving competitive position' and to increase the control of the market coverage. Then, profitability also is found to be improved after the firm combination.

Table 7

M\&A Performance Outcomes

\begin{tabular}{lccc}
\hline \multicolumn{1}{c}{ M\&A Performance Item } & Mean & $\begin{array}{l}\text { Standard } \\
\text { Deviation }\end{array}$ & Variance \\
\hline Market share & 5.63 & 0.90050 & 0.811 \\
Profitability (Return on investment) & 5.54 & 0.96736 & 0.936 \\
Competitive position & 5.62 & 0.93084 & 0.866 \\
Market coverage & 5.61 & 1.07072 & 1.146 \\
Customer satisfaction & 5.11 & 0.96920 & 0.939 \\
\hline
\end{tabular}

\section{Conclusion}

The cross-border M\&A's pattern deciphered in the study is important to provide a foundation for further research in mergers and acquisitions particularly in Malaysian and Indonesian contexts. Although this study focused on the presentation of data, the patterns of cross- 
border M\&A among Malaysian and Indonesian multinational firms, demonstrates a trend of 'horizontal combination' is found to be the most dominant. The data also revealed that most Malaysian multinational firms acquired firms that are basically in their neighbouring country viz., Indonesia, Singapore, Thailand and other continents such as India and China. This means Malaysian multinationals are keen to take high risk to acquire firms that they are familiar with. This trend is also similar to Indonesia.

The study also indicates that of the industries that have adopted M\&A strategy in expanding their business entities overseas, engineering, software and telecommunication industries are prominent. This is followed by financial services, automotive, machinery and plantation and agribusiness.

The study shows that Malaysian and Indonesian firms succeeded in integrating their business operations with the acquired firms even though the target firms are from different country background. This is substantiated by the fact that most of the performance measures such market share, competitive position, market coverage and profitability of the combined firm shows positive directions. Although the percentage of success in M\&A integration results are high but there is a need for future research to study the failure ones which can reveal why integration fails between two firms in cross-border M\&A. This is important as it can improve the capability of the firms to integrate with other firms especially when pursuing an international expansion through cross-border M\&A. Additionally, cross-border M\&A studies were often based on case study approach rather than a detailed survey method. Moreover, most of such studies are focussed on developed countries. This research, however describes the cross-border M\&A research in the continents of emerging countries particularly in the ASEAN region. Present work is an attempt to fill-in this gap and to document the underlying trends in cross-border M\&A by Malaysian and Indonesian firms.

\section{References}

Abidin, M. Z. (Ed.). (2008). PANORAMA. Kuala Lumpur: Konrad Adenauer Stiftung.

Ahsan, A. A. (2012). CIMB beli 60\% bank Filipina. Berita Harian.

Metwalli, A. M., \& Roger, Y. W. T. (2002). Southeast Asia: The next M\&A hotspot? Journal of Corporate Accounting \& Finance, 13(2), 39-47.

Allen, L., Julapa J., Stavros P., \& Anthony, S. (2004). The role of bank advisors in mergers and acquisitions. Journal of Money, Credit \& Banking, 36(2), 197-224.

Angwin. (2001). Mergers and acquisitions across European borders: National perspectives on preacquisition due diligence and the use of professional advisors. Journal of World Business, 36(1), 32. 
Mohd Haniff Jedin

Aspan, M. (2009). An M\&A consultant forms advisory firm. American Banker, 174(73), $5-5$.

Barrock, L. (2006). GLC story: The next chapter. The Edge.

Cording, M., Petra, C., \& David, R. K. (2008). Reducing causal ambiguity in acquisition integration: Intermediate goals as mediators of integration decisions and acquisition performance. Academy of Management Journal, 51(4), 744-67.

Dilman, D. A. (2007). Mail and Internet surveys 2007: With new Internet, visual, and mixedmode guide: The tailored design method. New Jersey: Wiley and Sons.

Fladmoe-Lindquist, K. (1996). International franchising: Capabilities and development, Journal of Business Venturing, 11(5), 419-38.

Colombo, G., Conca, V., Buongiorno M., \& Gnan, L. (2007). Integrating cross-border acquisition: A process-oriented approach. Long Range Planning, 40, 202-22.

Gaughan, P. A. (2002). Mergers \& acquisitions and corporate restructurings. New York: John Wiley \& Sons, Inc.

Ghauri, P. N., \& Peter, J. B. (2003). International mergers and acquisitions: Past, present and future. Advances in Mergers and Acquisitions, 2: JAI.

Homburg, C., \& Matthias, B. (2005). A marketing perspective on mergers and acquisitions: How marketing integration affects post merger performance. Journal of Marketing, 69(1), 95-113.

Hopkins, H. D., Chaganti, R., \& Masaaki, K. (1999). Cross-border mergers and acquisitions: Global and regional perspectives. Journal of International Management, 5(3), 20739 .

Hunter, W. C., \& Julapa, J. (2003). An analysis of advisor choice, fees, and effort in mergers and acquisitions, Review of Financial Economics, 12(1), 65-81.

Jayaseelan. R., \& Yeap, C. (2006). TM lands Indian's Spice. The Edge.

Kish, R. J., \& Vasconcellos, G. M. (1993). An empirical analysis of factors affecting crossborder acquisitions: U.S. - Japan. Management International Review, 33(3), 22745 .

Kitching, J. (1967). Why do mergers miscarry? Harvard Business Review, 45(6), 84-101. 
Kusewitt, J. B. (1985). An exploratory study of strategic acquisition factors relating to performance. Strategic Management Journal, 6(2), 151-69.

Larsson, R., \& Sydney, F. (1999). Integrating strategic, organizational, and human resource perspectives on mergers and acquisitions: A case survey of synergy realization, Organization Science, 10(1), 1-26.

Prathaban, V. (2006). Proving there's life beyond 3G. Malaysian Business.

Richey, R. G., Timothy, S. K., Mert, T., \& Vivek, D. (2008). Market growth through mergers and acquisitions: The role of the relationship marketing manager in sustaining performance. Industrial Marketing Management, 37(4), 394-406.

Shanmugam, B., \& Mahendran, N. (2003). Mergers and acquisitions of banks in Malaysia. Managerial Finance, 30(4), 1-18.

Shimizu, K., Hitt, M. A., Vaidyanath, D., \& Vincenzo, P. (2004). Theoretical foundations of cross-border mergers and acquisitions: A review of current research and recommendations for the future. Journal of International Management, 10(3), 30753.

Sudarsanam, S. (2003). Creating value from mergers and acquisitions: The challenges. London: Pearson Education.

United Nations. (2000). World investment report 2000: Cross-border mergers and acquisitions and development. New York and Geneva: United Nations.

Zaheer. (1995). Overcoming the liability of foreignness. Academy of Management Journal, $38(2), 341-64$. 
